\title{
The Burden of Allergic Rhinitis: A Mini-Review
}

\author{
Michael AB Naafs* \\ Naafs International Health Consultancy, Europe
}

Submission: January 12, 2018; Published: January 23, 2018

*Corresponding author: Michael AB Naafs, Internist-endocrinologist with a long clinical career in internal medicine and endocrinology, Naafs International Health Consultancy, Dutch, Europe, Email: michael.naafs@hotmail.com

\begin{abstract}
The burden of allergic rhinitis (AR) is rising alongside industrialization,globalisation, climate change and air pollution with a steep increase in the last decades. AR affects about 50 million people in the U.S. Regions with a high incidence of AR show a high incidence of asthma as well. Combined costs are estimated at $\$ 80$ billion a year.In this mini-review pathogenesis,pathophysiology and management of AR are discussed with a special emphasis on allergen-specific immunotherapy.

Abbreviations: AR: Allergic Rhinitis; AAAAI: Allergy, Astma and Immunology; APCs: Antigen-Presenting Cells; DCs: Dendritic Cells; TGF-Beta: Transforming Growth Factor-Beta; CTLA-4: Cytotoxic T-Lymphocyte Antigen-4; PD-1: Programmed Death; SPTs: Skin Prick Tests; BSACI: British Society of Allergy and Clinical Immunology; INS: Intransal Corticosteroids; FBC: Full Blood Count; FLAP: Co-Factor 5-Lipoxygenase-Activating Protein; SCIT: Subcutaneous Allergen Immuno Therapy; SLIT: Sub Lingual Immuno Therapy; AIT: Allergen Immuno Therapy; CF: Cerebrospinal Fluid
\end{abstract}

\section{Introduction}

Allergic rhinitis (AR) has a considerable effect on quality of life. AR is a possible cause factor in comorbid diseases such as comorbid asthma,chronic sinusitis,otitis media,upper respiratory infection and nasal polyposis. Nasal congestion,the most prominent symptom is associated with sleep disordered breathing,a condition that can have a profound effect on mental health [1-6]. AR imposes a high socioeconomic burden,particularly in terms of indirect costs [7-11]. According to the American Academy of Allergy,Astma,and Immunology (AAAAI) roughly $7,8 \%$ of people over 18 and over in the U.S. have hay fever [6]. Worldwide allergic rhinitis affects between $10 \%$ and $30 \%$ of the population $[7,8]$. Nasal allergies affect about 50 million people in the U.S. They affect as many as $30 \%$ of adults and $40 \%$ of children [8]. Epidemiological data have shown a rapid increase in the prevalence of AR in the past decades $[9,10]$.The incidence of AR was lower than $1 \%$ in the 1920 's and began to increase after the industrial revolution,slowly in the 1950's-1980's,but sharply since at least 1990 [11]. The prevalence of AR is stronly associated with asthma and the incidences of both are on the rise,in both developed countries [11-13].

Regions with a high incidence of AR show a high incidence of asthma as well [14]. AR, like skin rashes and other allergies,develops when the body's immune system becomes sentisised and overreacts to something in the environment that typically causes no problem in most individuals, Recently, the concept of polysenstitsation has drawn attention in a Dutch study,showing a 5 -fold increased risk of polysensitisation in children with atopic dermatitis. The skin barrier defect appeared to be specific,when it comes to facilitating transcutaneous sensitisation in children [15]. Transcutaneous sensitisation to multiple allergens occurs early in life and is associated with a more severe atopic and asthmatic phenotype later in life [15]. With an estimated cost of $\$ 5,3$ billion a year AR is a significant burden on patients and society [16]. AR is a multifactorial disease,including genetic,immunological and environmental pollutants as a causal factor [17]. In this mini-review pathogenesis,pathophysiology and management of AR will be discussed with a special emphasis on allergen -specific immunotherapy.

\section{Pathogenesis of AR}

AR is a prototype of IgE-mediated disease. The hallmark of allergic rhinitis is an IgE-mediated type 1 hypersensitivity reaction to an inciting inhaled allergen. Genetic predisposition and environmental factors,including allergen exposure to environmental adjuvans or immune response suppressors,probably exert important influences on the development of AR. Allergens implicated in AR are in the vast majority proteins that derive from airborne particles including pollens moulds, animal dander and environmental pollutants. After inhalation of allergenic particles, they are eluted in nasal mucus and subsequently diffuse into nasal tissues. The sensitisation process is initiated in nasal tissue,when 
antigen-presenting cells (APCs), which are primarily dendritic cells,engulf allergens,break them into allergenic (antigenic) peptides and migrate to lymph nodes,where they present these peptides to naive (never exposed to antigen) yet epitope-specific CD4+ T lymphocytes ( $\mathrm{T}$ cells)-[18,19]. CD4+ lymphocyte activation requires the interaction of specifc $\mathrm{T}$ cell receptors with allergen peptide-MHC class 2 complexes on the APCs and the ligation of co-stimulatory receptors of the CD 28 family on $T$ cells by B 7 family members of co-stimulatory molecules (CD80 and CD86) on APCs [20]. Naive helper T cells are known as Th 0 cells,because they produce a pattern of cytokines,that spans both the Th 1 and Th 2 phenotype.If given the proper stimulus naive helper $\mathrm{T}$ cells can differentiate in the biased Th 1 and Th 2 subset.

In the case of allergy,the Th 2 subset plays a central role.In the development of Th 2 cells,interleukin-4 ( IL-4) is a required stimulus [21]. Dendritic cells (DCs) form a network that is localized within the epithelium and submucosa of the entire respiratory mucosa,including the nasal mucosa.The number of both DCs and T cells at the surface of the nasale epithelium is increased in rhinitis [22]. In addition, to presenting antigen,DCs can polarize naive T cells in either Th 1 or Th2 cells according to their own phenotype,and with signals received from processed antigens and from the tissue environment during antigen presentation.Contacts with a virus promote a Th1 phenotype and cytokines as IL-3,prostaglandin E2 and thymic stromal lymphopoetin released from epithelial cells promote a Th 2 phenotype $[23,24]$. A distinct subtype of $\mathrm{T}$ cells,the so called regulatory $\mathrm{T}$ cells (Tregs) suppress immune response (both Th2 and Th1) through the inhibitory cytokines and cell surface molecules,including IL-10 and transforming growth factor-beta (TGF-beta), cytotoxic T-lymphocyte antigen -4 (CTLA-4) and programmed death-1 (PD-1). Tregs can also inhibit effector T cells via a direct cell-cell contact mechanism to induce apoptosis.In addition,Tregs crosstalk with APCs to suppress T cell activation. Tregs are categorized as natural or adaptive (inducible $\operatorname{Tr} 1$ ). The former are characcterized by the expression of high levels of CD 25 on their surface and by the transcription factor forkhead box P3 ( Fox P3)-[25].

Both nonallergic and allergic individuals retain allergicspecific IL-4 producing effector T cells,IL-10 producing Tr 1 cels and CD25+ Tregs,but in different proportions. Thus the balance between Th 2 and certain Treg populations may decide whether clinical allergy will develop. Ig E,like all immunoglobulins is synthesized by B lymphocytes (B cells) under the regulation of cytokines derived from Th 2 lymphocytes.Two signals are required. Il-4 or IL-3 provides the first essential signal that drives B cells to IgE production by inducing epsilon-germline gene transcription. In the case of IgE-expressing memory B cells, these cytokines induce clonal expansion. The second signal is a co-stimulatory interaction between CD 40 ligand on the T-cell surface and CD 40 on the B-cell surface. This signal promotes B-cell activation and switch recombination for the production of
IgE [26-29]. Once produced by B-cells IgE antibodies attack on high-affinity receptors (FceR1) on the surface of mast cells and basophils,rendering them "sensitized". This induces the classical allergic reaction at the cellular level.

\section{Pathophysiology of AR}

About the inflammatory consequences of AR in the nose and the role of many biological products,many assumptions are made.Information is obtained from snapshot imaging of the nasal mucosa from animal models and from basic knowledge about the in vitro activity of various mediators,chemokinines,cytokines and so on. Yet,little confirmation is available on the precise role of the in vivo setting in AR,as pharmacologic or other inhibitory or blocking approaches do not exist or failed to produce significant clinical results.IgE coats the mast cells. When the specific protein ( eg pollen,grain) is inhaled into the nose,it can bind to the IgE on the mast cells,leading to immediate and delayed release of mediators [30-32]. The mediators that are immediately released include,histamine,tryptase,chymase,kinins and heparins [31,32]. The mast cells quickly synthesize other mediators,including leukotrienes and prostaglandin D 2 [3335]. These mediators lead to the symptoms of rhinorrhea, (ie, nasalcongestion,sneezing, itching,redness, tearing,swelling,ear pressure and postnasal drip). Mucous glands are stimulated,leading to increased secretions.Vascular permeability is increased,leading to plasma exudation. Vasodilatation results in congestion and pressure.Sensory nerves are stimulated,resulting in sneezing and itching.All of these events can occur in minutes. This is called the early or immediate phase of the allergic reaction.

The late phase response occurs 4-8 hours later. Recruitment of other inflammatory cells to the nasal mucosa,such as neutrophils,eosinophils,lymphocytes and macrophages ,is ordered [36]. The symptoms of the late phase are similar to the early phase,but with less sneezing and itching and more congestion and mucus production. The late phase may persist for hours or days. Systemic effects including fatique,sleepiness and malaise can occur,contributing to impaired quality of life [36]. Irritant triggers such as smoke,nicotin,pollution and strong smells can aggrevate symptoms in a patient with AR. These are also common triggers of vasomotor rhinitis.Many patients have both AR and vasomotor rhinitis [37]. Other patients describe year round symptoms, instead of seasonal AR.This could be consistent with nonallergic rhinitis,but perennial allergens,such as dust mite or animal exposure should also be considered in this situation.With chronic exposure and chronic symptoms, the patient may not be able to associate symptoms with a particular trigger [38]

\section{Diagnosis of AR}

Recently,the British Society of Allergy and Clinical Immunology (BSACI) released updated guidelines for the diagnosis and management of AR and non-allergic rhinitis,first published in 2007 by its Standards of Care Committee [39]. 
For the diagnosis AR a detailed history is required including seasonality (pollen,moulds),indoors or outdoors location (dust mite,presence of house pets), work location (occupational), improvement of holidays and relationship to potential triggers which can impact on the patient's quality of life. Rhinorrhea is either anterior,posterior or both. Secretions can be clear or yellow-green indicating infection. Nasal obstruction can be partial or complete and the severity often correlates with systemic manifestations. Unilateral obstruction is most likely due to septal deviation,while bilateral obstruction is caused mostly to rhinitis or nasal polyps.Severe crusting especially high inside the nose is an unusual symptom in rhinitis and requires further investigation. The eye symptoms of AR include intense itching,redness and swelling of the white of the eye,watering,lid swelling and in severe cases periorbital edema,which can be aggrevated by eye rubbing.Lower respiratory tract symptoms as cough, wheeze, shortness of breath can occur with AR alone,since bronchial hyperreactivity can be induced by upper airway inflammation [40,41].

Disorders of the upper and lower respiratory tract often coexist.Eighty percent of asthmatics have AR. Other symptoms associated with AR are snoring sleep problems,repeated sniffing,and nasal intonation of the voice. The pollen-food syndrome is triggered by ingestion of cross-reacting antigens in some fruits,vegetables and nuts [42]. A proportion of patients suffering from AR,mainly seasonal, have an associated hyperreactivity,which is generally not recognized or treated. A diagnosis of AR is more likely when rhinitis is seasonal or with a family history of AR. However it can arise de novo. A number of drugs can cause or aggrevate AR symptoms. A drug history should include details of the use of alpha-and beta blockers and other antihypertensives (ACE inhibitors), aspirin and NSAIDs, cocaine and chlorpromazine, alcohol, spicy foods, peppers and sulphites,and oral contraceptives. At anterior rhinoscopy hypertrophic,pale and boggy inferior or middle turbinates suggest inflammation,but nasal appearance may be normal in AR.Nasal endoscopy is more specific than rhinoscopy and alters the diagnosis in up to a fifth of patients with nasal disease [43]. Allergen-specific IgE can be detected with skin prick tests ( SPTs) or by serum immunoassay (RAST). SPTs should be carried out routinely to determine if the rhinitis is allergic or nonallergic and have a high negative predictive value.They should be interpreted in the light of the clinical history.

At least $15 \%$ of people with a positive SPT do not develop symptoms on exposure to the relevant allergen. [44]. Prick to prick tests with fresh food can be used to diagnose oral allergy syndrome. Serum IgE may be requested when skin tests are not possible or when the SPT together with the clinical history give unequivocal results. Currently available SPTs and allergen-specific IgE show similar sensitivity for house dust mite,but SPTs are more sensitive to other inhalant allergens such as cat epithelium,mould and grass pollen. [45]. Laboratory investigations are guided by the history,examination and results of SPTs They can include: Full blood count (FBC) and differential white cell count; C-reactive protein,immunoglobulin profile,microbiological examination of sputum and sinus swabs,when chronic infection is suspected. In unexplained nasal obstruction thyroid function tests can be ordered. Asialotransferrin assay is used for identification of CSF (cerebrospinal fluid) leakage. Urine toxicology is performed when cocaine abuse is suspected. The presence of eosinophils in cytologic specimen may be helpful in predicting response to corticosteroids $[46,47]$. Radiology is not routinely recommended for simple rhinitis.However,when rhinosinusitis or nasal polyposis is suspected,especially non-responsive to therapy, CT scan is helpful. Nasal challenge may be useful to confirm aspirin sensitivity or in occupational rhinitis.Measurements of lung function should be considered in all patients with persistent rhinitis.ENT referral is required for patients with unilateral symptoms, heavily blood stained discharge or pain. Those with nasal blockage unrelieved by pharmacotherapy or structural abnormalities,such as septal deviation,making nasal therapy difficult, should be seen by an ENT surgeon.

\section{Management of AR}

Allergen avoidance clearly works in seasonal allergy rhinoconjunctivitis,which is traditionally in spring. However,climate change might prolong the pollen season.This extension of the pollen season could be due to a prolonged flowering time of certain species,or the appearance of new species, that flower in late summer eg common ragweed.Trees such as birches and planes might produce larger quantities of pollen,which could result in more severe symptoms.Climate change could cause an increase in heavy thunderstorms on summer days in the grass pollen season,,which are known to increase the chance of asthma exacerbations. Hay-fever season will be prolonged through the year [48]. For patients with house dust mite-sensitive AR,the situation is complicated by the difficulties of reducing exposure to mites in the home.A systematic review of trials of mite allergen avoidance in rhinitis concluded that trials are generally small and of poor methodologically quality and meta-analysis could not be performed [49]. Large studies of a combination of strategies to reduce exposure to dust mites have not been conducted,but should probably include measures to reduce mites in cars,at school and work. For occupational AR complete avoidance of exposure to the causal agent is recommended [50].

a. Allergen avoidance measures that can be taken are:

b. Encase matress, pillow and duvet in allergenimpermeable fabric,

c. Use of acaricides on carpets and soft furnishing,

d. minimizing outdoor activity when pollen is highest (early morning,early evening,during mowing),

e. Avoiding going out during or after thunderstorms 
f. keeping windows closed(house and car),

g. Shower/wash hair following high exposure,

h. Avoid drying washings outdoors when pollen count is high,

planning holidays to avoid the pollen season. Irritants such as smoke,traffic pollution can worse AR symptoms and should be avoided, where possible. Interventions that may help to reduce symptoms during the pollen season include patients wearing sunglasses (GradeC), balms and ointments applied to the nose [51-53]. In a DBRPC (double blind,randomized,placebocontrolled) study the application of a cellulose powder (Nasileze $\mathrm{TM}$ ), three times daily,resulted in significant reductions in severity scores for sneezing,runny nose,stuffy nose and symptoms from eyes and lower airways,with no clinically significant adverse effects [54]. For patients with AR sensitized to and symptomatic on contacts with pets such as cats,dogs and horses avoidance of the animal should be advised.For those ,who wish to keep pets to which they are sensitized there is limited information from randomized studies on which to base recommendations [55]. HEPA(High Efficiency Particulate Air) filters alone do not seem useful for cat allergic patients with cats.Cat allergen expoure can be reduced using temperature controlled laminar air flow treatment [56] and although this treatment has shown to improve asthma-related quality of life,this has not been tested for AR [57]. Isotonic saline irrigation in both adults and children was well tolerated [58], inexpensive,easy to use and with no evidence of adverse effects to health with regular use $[59,60]$. The use of a ten second burst of carbon dioxide from a pressured container into the nasal airway,with the mouth open,reduces all the symptoms of AR within minutes.It is now available over the counter for rescue treatment as Serenz [61,62].

\section{Pharmacotherapy of AR}

Allergen and irritant avoidance are difficult and many rhinitis sufferers continue to have persistent symptoms, the nature of which should select the medication.Following diagnosis and classification (AR,Non-AR Vasomotor Rhinitis ,Mixed AR) according to disease severity a stepwise pharmacotherapeutic approach should be introduced. A combimation of treatments is often needed for more severe disease an it is here that the option of immunotherapy should also be considered.

\section{Antihistamines in AR}

Antihistamines are available as oral,intranasal and ocular preparations.All demonstrate clinical efficacy.Second generation antihistamines are long-acting and are largely non-sedating and have no clinically significant anticholinergic activity at therapeutic doses,although there is variation in individual susceptibility to such effects [63]. Oral antihistamines reduce mean daily rhinitis symptoms scores,in absolute terms, by an estimated $7 \%$ versus placebo [64], and can significantly improve quality of life $[65,66]$. They act predominantly on neurally mediated symptoms of itch,sneeze and rhinorrhea and have only a modest effect on nasal congestion [67-73]. Additionally, they reduce histamine driven symptoms as itch [74] at sites other than just the nose as conjunctiva, palate and skin [75-77]. They should be used regularly rather than "as needed" use in persistent rhinitis $[78,79]$. Acrivistine has the fastest onset of action,but needs to be used 8 hourly.Fexofenadine is the least sedating oral anti-histamine with a wide therapeutic index. First generation antihistamines are less useful due to sedation and cognitive impairment,which can worsen driving and examination results already impaired by rhinitis $[5,80]$. Their use s not recommended. Antihistamines with an anti-cholinergic effect are associated with dementia [81].

Second generation antihistamines as terfenadine and astimezole were implicated in deaths from ventricular fibrillation via QT interval prolongation [82]. Ebastine and mizolastine also need to be used with caution in those with cardiac risk factors [83], but even ceterizine,desloratidine,diphenhydramine, fexofenadine, loratidine were possibly associated with cardiac arrythmias in a single large European pharmacovigilance study [84]. Antihistamines have a place in first line therapy for mild to moderate intermittent and mild persistent rhinitis,and as an addition to intranasal steroids for moderate persistent severe rhinitis uncontrolled on topical intranasal corticosteroids alone,particularily when eye symptoms are present [85-87]. Topical H1-antihistamines are superior in attenuating rhinitis symptoms [88] and in decreasing nasal obstruction to oral antihistamines), although they do not improve symptoms due to histamine at other sites,such as skin $[89,90]$. There is a rapid onset of action (15minutes),faster than oral antihistamines [91]. They can be effective in patients who have previously failed oral antihistamines. Treatment with both an intranasal and oral antihistamine confers no additional advantage in alleviating nasal symptoms [92]. They are less effective than an intranasal steroid in relieving the symptoms of allergic rhinitis.Adverse effects include local irritation and taste disturbance (dysgeusia) with azelastine [93].

\section{Corticosteroid therapy in AR}

Topical corticosteroids are the mainstay of anti-inflammatory interventions in AR. Factors which need consideration are systemic drug bioavailability,safety and cost [94]. Ease of device use may influence concordance. Intransal corticosteroids (INS) reduces all symptoms by about $17 \%$ more than placebo,with a variable effect on associated allergic conjunctivitis $[95,96]$. Meta-analysis shows that INS is superior to oral antihistamines or leukotriene receptor antagonist alone on all aspects of allergic rhinitis [64,97]. Onset of action is 6-8 hours after the first dose,clinical improvement may not be apparent until after 2 weeks [97]. Starting treatment two weeks prior to a known allergy season improves efficacy [98]. Clinical efficacy is similar for all INS, but bioavailability varies considerable. The systemic absorption is neglgible with mometasone fuorate,fluticatisone fuorate and fluticasone propionate and these preparations are favoured for children.Systemic absorption is modest for the 
remainder,and high for betamethasone which should be used short-term only $[99,100]$. Local nasal irritation, sore throat and epistaxis affect around 10\% of users.Reduction of local adverse effects,such as nasal crusting,bleeding and pain can be achieved in many cases by correct use of the intranasal device.Nasal drops are useful for severe obstruction and should be used in the "head upside down"position to reach the ostiomeatal complex. Raised intra-ocular pressure has been described with INS, thus limiting its use in patients with a predisposition to high ocular pressure or glaucoma [101]. INS are a first line of therapy for moderate to severe persistent symptoms [101], possibly combined with a short-term nasal decongestant $[97,102]$.

\section{Combination therapy in AR}

INS demonstrate similar or greater efficacy to an oral antihistamine plus a leukotriene receptor antagonist [103,104]. Currently available as a combination spray containing azelastine anf fluticasone propionate,Dysmysta, leads to greater symptom improvement,than using either agent alone in seasonal AR [105]. All symptoms of allergic rhinitis were significantly improved with onset of action by 30 minutes [106]. The combination approach leads to clinical improvement of symptoms earlier than with azelastine or fluticasone monotherapy [105]. Ocular symptoms of allergy were better treated with the combination spray rather than fluticasone or azelastine alone [106]. Efficacy over fluticasone is demonstrated in perennial allergic rhinitis [107]. Combination of topical antihistamines with INS should be used in patients when symptoms remain uncontrolled on antihistamines or INS or on a combination of both. There are no trials of oral steroid use and efficacy in AR, although there is grade A evidence in chronic rhinosinusitis with nasal polyposis where inflammation is more severe. During severe exacerbation despite compliance on conventional pharmacotherapy, it is important to ensure intranasal steroid therapy is co-administered alongside oral steroids with or without a short-term decongestant spray to allow intranasal drug penetration.

There is no definite consensus on the dose and duration of systemic steroid therapy. A suggested regime for adults is $0,5 \mathrm{mg}$ per $\mathrm{kg}$ for 5-10 days.Frequent oral steroid rescue should prompt immunotherapy as a treatment option. Topical decongestant formulations allow relief of nasal congestion via vasoconstriction within minutes,faster and with greater impact than intranasal steroids $[108,109]$. A decongestant spray may allow delivery of intranasal drugs beyond the inferior turbinates.For example,oxymetazoline and fluticasone fuorate when used together further improved nasal congestion more than either alone [109]. Only short term use,fewer than 10 days, is recommended as a paradoxical increase in nasal congestion secondary to rebound vasodilatation (rhinitis medicamentosa) can occur [110]. Topical decongestants are used in eustachian tube dysfunction when flying. They are used to increase nasal patency before douching or intranasal administration of nasal steroids [111]. Oral decongestants,pseudoephedrine, are weakly effective in reducing symptoms [112] and have many side effects,so they are not recommended [113].

\section{Anti-leukotrienes in AR}

Two approaches have been taken to developing antileukotriene drugs. The first is the development of synthesis inhibitors that are either direct inhibitors of the 5-lipoxygenase enzyme or antagonists of the essential cofactor 5-lipoxygenaseactivating protein (FLAP)-[114]. The second approach has been to develop receptor antagonists.Zyflo is a 5-lipoxygenase inhibitor. Montelukast (Singular), pranlukast(ONON), and zafirlukast (Accolate) are leukotriene receptor antagonists (LTRAs)-[114]. They have a therapeutic profile similar to antihistamines,with efficacy comparable to loratidine in seasonal AR [115], and are less effective than topical nasal corticosteroids (INS)-[115-118]. The response is less consistent than that obseved with antihistamines [118-120]. LTRAs reduce rhinitis symptoms by $5 \%$ more than placebo [64]. Combination of an antileukotriene plus antihistamine has no advantage over either drug used alone [121-125], and is not any more effective than INS alone [101,125]. Antileukotrienes may have a place in patients with seasonal AR [126]. They are usually well tolerated. Occasionally,headache,gastrointestinal symptoms or rashes can occur.Neuropsychiatric symptoms have been reported in children.There is a possible causal link between LTRA use and eosinophilic polyangiitis $[127,128]$.

\section{Topical anticholinergics in AR}

Ipratropium bromide decreases rhinorrhea,particularily if neurogenic rather than inflammatory,in origin. It has no effect on other nasal symptoms [129-133]. Regular use may be effective as an "add on" for allergic rhinitis when watery rhinorrhea persists despite INS and antihistamines [130,133].

\section{Chromones in AR}

The chromones sodiumcromoglycate and nedocromil sodium inhibit the degranulation of sensitized mast cells,inhibiting the release of mediators [134]. Sodium cromoglycate is weakly effective in rhinitis with some effect on nasal obstruction $[135,136]$. Cromoglycate and nedocromil eye drops are useful in conjunctivitis as topical therapy [137].

\section{Immunotherapy in AR}

Allergen immunotherapy (AIT) is the only class for respiratory allergy that has the potential to change the course of the disease. Its immunological mechanisms of action involve induction of allergen-specific immune tolerance.Respiratory allergy is nowadays considered a single condition which affects both upper and lower airways integrated in the "one airway"concept. The association of allergic rhinitis (AR) and asthma has been extensively established and the common mechanistic pathways leading to inflammation also share multiple characteristics.Also, it is well known that AR frequently precedes the onset of asthma,allowing a window of opportunity 
for intervention [102]. AIT is the similtaneous treatment of all clinical expressions of respiratory allergy,that is from rhinoconjunctivitis to asthma [138]. AIT may be preventive in two modes; decreasing the risk of developing asthma in patients which only suffer AR and diminishing the tendency of the allergic patients to become sensitized to further allergens [139].

\section{Subcutaneous allergen immunotherapy in AR}

Subcutaneous allergen immunotherapy (SCIT) has extensively been evaluated in AR,as this has been the primary indication of AIT. Data provided by different meta-analysis of published trials have shown,That it is an effective treatment,decreasing both symptom and medication scores [140,141]. In a Cochrane metaanalysis for both seasonal rhinitis due to pollens the evidence level was1+++ and for perennial rhinitis due to house dust mite the evidence level was $1+[140,142]$. There are few randomized controlled trials of immunotherapy for cat allergy [143,144]. SCIT requires weekly up-dosing regimens,followed by 4-6 weekly maintenance injections for 3-5 years. Pre-seasonal SCIT is effective for pollen allergy. In view of the risk of systemic sideeffects SCIT should only be given in specialist clinics by trained personnel with immediate access to adrenaline and resuscitation facilities [145].

\section{Sublingual immunotherapy in AR}

In the last decades sublingual immunotherapy (SLIT) has become a widely used form of AIT.Again meta-analysis of studies has assessed its efficacy,indicating a reduction in symptoms and the need of medication [146-148]. Nevertheless,and despite meta-analysis are nowadays considered to hold the highest degree of evidence,critical appraisals have been published and should also be carefully considered [149,150]. Assessment of ATI in asthma has only been adequately reported in trials to address this aim.In trials where the primary indication of AIT was rhinitis,it is difficult to infer the effect on asthma symptoms,either because they have not been examined,because patients with asthma symptoms were excluded,or because the low number of patients with asthma or the mildness of the disease renders underpowered results to draw conclusions [151,152]. A recent Cochrane review on SLIT for asthma was unable to reach conclusions on the efficacy due to the lack of data for important outcomes such as exacerbations and quality of life and use of non-validated symptoms and medication scores according to the authors [153]. SLIT has emerged as an effective and safe alternative for the treatment of allergic rhinitis with or without seasonal asthma. SLIT is well tolerated with side effects largely confined to local itching and swelling in the mouth and the throat.

After supervision of the first dose by the prescribing physician with a one-hour period observation, SLIT is selfadministered daily at home. SLIT has an excellent safety record,although there are case reports of systemic reactions and of eosinophilic oesophagitis,but no deaths have been reported. Oral antihistamines given prior to SLIT initation and for the first two weeks of the course of therapy can reduce local irritaton. Recently,Odactra (Merck), a house dust mite (Dermatophagoides faminae and Dermatophagus pteronyssinus,allergen extract was approved by the FDA (March,1,2017), for the treatment of adults aged 18-65 years with house dust mite (HDM) induced AR,with or without conjunctivitis,confirmed by in vitro testing for IgE antibodies to Dermatophagoides pteronyssinus house dust mite,or skin testing to licensed house dust mite allergen extracts. Odactra is not indicated for the immediate relief of symptoms of HDM allergy. The safety and efficacy of Odactra were evaluated in a large clinical trial program that included over 6000 patients [154]. Immunotherapy is the only treatment that can modify the course of allergic rhinitis (AR), with longterm remission following discontinuation [155]. Subcutaneous immunotherapy in children with seasonal rhinitis reduces progression to asthma, an effect that persisted for 10 years [155]. Immunotherapy may prevent development of new sentisations.

\section{Complementary therapies in AR}

The evidencelevels for all complementary therapies,including acupuncture,herbal medicine,phototherapy and homeopathy are not considered sufficient for recommendation in AR.

\section{Conclusion}

Allergic rhinitis (AR) is a rising burden on patients and society since tha last decades. Industralization,globalisation, air pollution and climate change play a definite role. About the inflammatory consequenses of AR in the nose and the role of biological products many assumptions are made.Information is obtained from a snapshot imaging the nasal mucosa of animal models and from basic knowledge about the in vitro activity of various mediators,chemokinines,cytokines,etc. Yet,little information is available on the precise role of the in vivo setting. It is not known how aerial particulate matter triggers and interfere with the early and late phase allergic reaction. Allergen avoidance is notably difficult.Antihistamines score $7 \%$ better than placebo [64] and intranasal steroids score $17 \%$ better than placebo, with a variable effect on associared allergic conjunctivitis $[95,96]$. Antileukotrienes have a similar profile to antihistamines and are less effective than topical corticosteroids. Topical anticholinergics decrease rhinorrhea rather than inflammation. The chromones inhibit the degranulation of mast cells inhibiting the release of mediators.They are weakly effective in AR and nasal obstruction.Only allergen immunotherapy (AIT) is able to change the course of AR.As AR frequently precedes the onset of asthma,AIT offers a window of opportunity for intervention [102] Subcutaneous immunotherapy (SCIT) in children with seasonal AR reduces progression to asthma,an effect that persisted for 10 years [155]. Immunotherapy prevents developments of new sentisations $(159,160)$ Sublingual immunotherapy has emerged as an effective and safe alternative for the treatment of AR and is self-administered at home after a supervised firstdose observation.Future research shoud be directed at the role of triggers as nicotin,smoke and particulate matter in the immunology process involved in AR. 


\section{Global Journal of Otolaryngology}

\section{References}

1. Price D, Scadding G, Ryan D, Claus Bachert, G Walter Canonica, et al. (2015) The hidden burden of allergic rhinitis: UK healthcare resource utilisation survey. Clin Transl Allergy 5: 39.

2. Lamb CE, Ratmer PH, Johnson CE, Ambegaonkar AJ, Joshi AV, et al. (2006) Economic impact of workplace productivity losses due to allergic rhinitis compared with select medical conditions in the United States from an employer perspective. Curr Med Res Opin 22(6): 1203-1210.

3. Hellgren J, Cervin A, Nordling S, Bergman A, Cardell LO (2010) Allergic rhinitis and the common cold-high cost to society. Allergy 65(6): 776-783.

4. Small M, Piercy J, Demoley P, Marsden H (2013) Burden of illness and quality of life in patients being treated for seasonal allergic rhinitis; a cohort survey. Clin Tramsl Allergy 3(1): 33.

5. Walker S, Khan Wasti S, Fletcher M, et al. (2007) Sesonal allergic rhinitis is associated with a detrimental effect on examination performance in United Kingdom teenagers: case control study. J Allergy Clin Immunol 120(2): 381-387.

6. Schiller JS, Lucas JW, Ward BW, Peregoy JA (2010) Summary Health Statistics for US adults: National Health Interview Survey 2010. Vital Health Stat (252): 1-207.

7. Panwankar R, Walkter G, Holgate ST (2011) World Health Organization: White Book on Allergy 2011-2012.

8. (2017) Allergy Statistics AAAAI 2017.

9. Yang G, Liu ZQ, Yang PC (2013) Treatment of allergic rhinitis with probiotics. N Am J Sci 5(8): 465-468.

10. Wang J, Wu J, Lui H (2015) Allergic Disease Epidemiology, Chapter 2 In: Allergy Bioinformatics, Translational Bioinformatics. Springer Science Business Media, Dordrecht.

11. De Marco R, Cappa V, Accordini S, Rava M, Antonicelli L, et al. (2012) Trends in the prevalence of asthma and allergic rhinitis in Italy between 1991 and 2010. Eur Respir J 39(4): 883-892.

12. Pesce G, Marchetti P, Girardi P, Alessandro Marcon, Lucia Cazzoletti, et al. (2012) Lattitude variation in the prevalence of asthma and allergic rhinitis in Italy: results from the GEIRD study. Eur Respir J 40: (S 56): 4777.

13. Sanjana JM, Mahesh PA, Yayaraj BS, KS Lokesh (2014) Changing trends in the prevalence of asthma and allergic rhinitis in children in Mysore, South India. Eur Respir J 44(58): 1187.

14. Khan DA (2014) Allergic rhinitis and asthma:epidemiology and common pathophysiology. Allergy Asthma Proc 35(5): 357-361.

15. Broeks SA, Brand PL (2016) Atopic dermatitis is associated with a five-fold increased risk of polysentisatisation in children. Acta Pediatrica.

16. Bhattachryya $N$ (2011) Incremental healthcare utilisation and expenditures for allergic rhinitis in the United States Laryngoscope 12(9): 1830-1833.

17. Higgins TS, Reh DD (2012) Environmental pollutants and allergic rhinitis. Curr Opin Otolaryngol Head Neck Surg 20(3): 209-214.

18. Godthelp T, Fokkens WJ, Kleinjan A, Holm AF, Mulder PG, et al. (1996) Antigen presenting cells in the nasal mucosa of patients with allergic rhinitis during allergen provocation. Clin Exp Allergy 26(6): 677-688.

19. Kleinjan A, Willart M, Van Rijt LS, Braunstahl GJ, Leman K, et al. (2006) An essential role for dendritic cells in human and experimental rhinitis. J Allergy Clin Immunol 118(5): 1117-1128.
20. Bugeon L, Dalmann M (2000) Costimulation of T cells. Am J Respir Crit Care Med 162(4): S164-S168.

21. Georas S, Guo J, Fanis U, Casolaro V (2005) T helper cell type-2 regulation in allergic disease. Eur Respirat J 26(6): 1119-1137.

22. Hartmann E, Graefe H, Hopert A, Pries R, Rothenfusser S, et al. (2006) Analysis of plasmacytoid and myeloid dendritic cells in nasal epithelium. Clin Vaccine Immunol 13(11): 1278-1286.

23. Liu YJ (2005) IPC: professional type 1 interferon producing cells and plasmacytoid dendritic cell precursors. Annu Rev Immunol 23 275-306

24. Bharadwaj AS, Bewtra AK, Agrawal DK (2007) Dendritic cells in allergic airway inflammation. Can J Physiol Pharmacol 85(7): 688699.

25. Maloy K, Powrie F (2001) Regulatory $\mathrm{T}$ cells in the control of immune pathology. Nat Immunol 2(9): 816-822.

26. Akdis M, Verhagen J, Taylor A, Fariba Karamloo, Christian Karagiannidis, et al. (2004) Immune response in healthy and allergic individuals are characterized by a fine balance between allergen-specific T regulatory 1 and T helper 2 cells. J Exp Med 199(11): 1567-1573.

27. Maggi L, Santarlasci V, Liotta F, et al. (1992) Demonstration of circulating allergen-specific CD4+ CD 25 high FoxP3+ T-regulatory cells in both nonatopic and atopic individuals. Geha R Regulation of IgE synthesis in humans. J Aller Clin Immunol 90: 143-150.

28. Henry AJ, Cook JP, McDonell JM, Graham A Mackay, Jianguo Shi, et al (1997) Participation of the $\mathrm{N}$-terminal region of $\mathrm{Ce} 3$ in the binding of human IgE to its high-affinity receptor FceR1. Biochemistry 36(50): 15568-15578.

29. Skoner DP (2001) Allergic rhinitis: definition, epidemiology, pathophysiology, detection and diagnosis. J Allergy Clin Immuno 108(1)S: 2-8.

30. Walls AF, He S, Buckley MG (2001) Roles of the mast cell and basophil in asthma. Clin Exp Allergy 1(2): 68-72.

31. Haberal I, Corey JP (2003) The role of leukotrienes in nasal allergy. Otolaryngol Head Neck Surg 129(3): 274-279.

32. Iwasaki M, Saito K, Takemura M, Sekikawa K, Fujii H, et al. (2003) TNF-alpha contributes to the development of allergic rhinitis in mice. J Allergy Clin Immunol 112(1): 134-140.

33. Cates EC, Gajewska BU, Chancharova S, Alvarez D, Fattouh R et al. (2003) Effect of GM-CSF on immune,inflammatory and clinical responses to ragweed in a novel mouse model of mucosal sensitization. J Allergy Clin Immunol 111(5): 1076-1086.

34. Salib RJ, Kumar S, Wilson SJ, Howarth PH (2004) Novel mucosal immunoexpression of the mast cell chemoattractants TGFbeta,exotaxin and stem cell factor and their receptors in allergic rhinitis. J Allergy Clin Immunol 114(4): 799-806.

35. Hansen I, Klimek L, Mosges R, Hörmann K (2004) Mediators of inflammation in the early and late phase of allergic rhinitis. Curr Opin Allergy Clin Immunol 4(3): 159-163.

36. Khazei HA, Khazei B, Dashtizadek GA, Mahdi Mohammadi (2015) Cigarette Smoking and Skin Prick Test in Patients with Allergic Rhinitis. Int J High Risk Behav Addict 4(3): e23483.

37. Saleh HA, Durham SR (2007) Perennial rhinitis. BMJ 335: 502

38. Scadding GK, Kariyawasam HH, Scadding, Andy T Clark (2007) BSAIC guideline for the diagnosis and management of allergic and non-allergic rhinitis. Clin Exp Allergy 47(7): 856-889.

39. Laitinen LA (1974) Histamine and metacholone challenge in the testing of bronchial reactivity. Scand J Respir Dis Suppl 86: 1-48. 


\section{Global Journal of Otolaryngology}

40. Laitinen LA, Kokkola K (1974) Bronchial reactivity to histamine in pulmonary tuberculosis. Scand J Respir Dis Suppl 89: 201-205.

41. Ortolani C, Ispano M, Pastorello E, Bigi A, Ansaloni R (1988) The oral allergy syndrome. Ann Allergy 616(2): 47-52.

42. Hughes RG, Jones NS (1998) The role of nasal endoscopy in outpatient management. Clin Otolaryngol Allied Sci 23(3): 224-226.

43. Droste JH, Kerkhof M, Monchy JG, Schouten JP, Rijcken B (1996) Association of skin test reactivity specific $\operatorname{IgE}$, total $\operatorname{IgE}$, and eosinophils with nasal symptoms in a community-based popukation study: The Dutch ECRHS Group. J Allergy Clin Immunol 97(4): 922932 .

44. Gleeson M, Cripps AW, Hensley MJ, Wlodarczyk JH, Henry RL, et al. (1996) A clinical evaluation in children of the Pharmacia ImmunoCAP system for inhalant allergens. Clin Exp Allergy 26(6): 697-702.

45. Romero JN, Scadding G (1992) Eosinophilia in nasal secretions compared to skin prick test and nasal challenge test in the diagnosis of nasal allergy. Rhinology 30(3): 169-175.

46. Nielsen HK, Eriksen EF, Storm T, Mosekilde L (1988) The effects of short-term,high-dose treatment with prednisone on the nuclear uptake of 1,25-dihydroxyvitamin D3 in monocytes from normal human subjects. Metabolism 37(2): 109-114.

47. De Weger LA, Hiemstra PS (2009) The effect of climate change on pollen allergy in the Netherlands. Ned Tijdschr Geneesk 153: A1410.

48. Nurmatov U, Van Schayck CP, Hurwitz B, Sheikh A (2012) House dust mite avoidance measures for perrenial allergic rhinitis: an updated Cochrane systematic review. Allergy 67(2): 158-165.

49. Raulf M, Buters J, Chapman M, Cecchi L, De Blay F, et al. (2014) Monitoring of occupational and environmental aeroallergens-EAACI Position Paper. Concerted action of the EAACI IG occupational and aerobiology\& air polution. Allergy 69(10): 1280-1299.

50. Ozturk AB, Celebroglu E, Karakaya G, Kalyoncu AF (2013) Protective efficacy of sunglasses on the conjunctival symptoms of seasonal rhinitis. Int Forum Allergy Rhinol 3(12): 1001-1006.

51. O’Meara IJ, Sercombe JK, Morgan G, Reddel HK, Xuan W, et al. (2005) The reduction of rhinitis symptoms by nasal filters during natural exposure to ragweed and grass pollen. Allergy 60(4): 529-532.

52. Kennedy R, Robertson L, Lewis M (2012) Haymax-confidential report Worcester. The National Pollen and Aerobiology Research Unit (NPARU) p. 1.

53. Aberg N, Ospanova ST, Nikitin NP, Emberlin J, Dahl §̊ (2014) A nasally applied cellulose powder in seasonal allergic rhinitis in adults with grass pollen allergy: a double-blind randomized, placebo-controlled, parallel-group study. Int Arch Allergy Immunol 163(4): 313-318.

54. Bjornsdottir US, Jakobinadottir S, Runarsdottir V, Juliusson S (2003) The effect of reducing levels of cat allergen ( Fel d1) on clinica symptoms in patients with cat allergy. Ann Allergy Asthma Immunol 91(2): 189-194.

55. Wood CC, Fireman P, Grossman J, Wecker M, MacGregor T (1995) Product characteristics and pharmacokinetics of intranasal ipratropium bromide. J Allergy Clin Immunol 955(2): 1111-1116.

56. Boyle RJ, Pedroletti C, Wickman M, Leif Bjermer, Erkka Valovirta, et al. (2012) Nocturnal temperature controlled laminar airflow for treating atopic asthma; a randomized controlled trial. Thorax 67(3): 215-221.

57. Jeffe JS, Bhushan B, Schroeder JW (2012) Nasal saline irrigation in children: a study of compliance and tolerance. Int J Paediatr Otolaryngol 76(3): 409-413.
58. Chen JR, Jin L, Li XY (2014) The effectiveness of nasal saline irrigation (seawater) in treatment of allergic rhinitis in children. Int J Pediatr Otolaryngol 78(7): 1115-1118.

59. Marchisio P, Varicchio A, Baggi E, Bianchini S, Capasso ME, et al. (2012) Hypertonic saline is more effective than normal saline in seasonal allergic rhinitis in children. Int J Immunopatol Pharmacol 25(3): 721-730.

60. Casale TB, Romero FA, Spierings EL (2008) Intranasal noninhaled carbondioxide for the symptomatic treatment of seasonal allergic rhinitis. J Allergy Clin Immunol 121(1): 105-109.

61. Casale TB, Korenblat PE, Meltzer EC, Yen K, Bhatnagar A (2011) Nasal carbon dioxide for the symptomatic treatment of perennial allergic rhinitis. Ann Allergy Asthma Immunol 107(4): 364-370.

62. Shamsi Z, Hindmarch I (2000) Sedation and antihistamines: a review of inter-drug differences using propertional impairment ratios. Hum Psychopharmacol 15(S1): S3-S30.

63. Wilson AM, O’Byrne PM, Parameswaran K (2004) Leukotriene receptor antagonists for allergic rhinitis: a systematic review and meta-anylysis. Am J Med 116(5): 338-344.

64. Bachert C, Bousquet J, Caronica GW, Durham SR, Klimek L, et al. (2004) Levocitrizine improves quality of life and reduces quality of life and reduces costs in long-term management of persistent allergic rhinitis. J Allergy Clin Immunol 114(4): 838-844.

65. Cipandri G, Cosentino C, Milanese M, Mondino C, Canonica GW (2001) Fexofenadine reduces nasal congestion in perennial allergic rhinitis. Allergy 56(11): 1068-1070.

66. Hore I, Georgalas C, Scadding C (2005) Oral antihistamines for the symptom of nasal obstruction in persistent allergic rhinitis:a systematic review of randomized clinical trials. Clin Exp Allergy 35(2): 207-212.

67. NayakAS, Schenke IE (2001) Desloratidine reduces nasal congestion in patients with intermittent allergic rhinitis. Allergy 56(11): 1077 1080.

68. Patou J, De Smedt H, Van Cauwenberge CP, Bachert C (2006) Pathophysiology of naal obstruction and meta-analysis of early and late effects of levocetrizine .Clin Exp Allergy 36(8): 472-481.

69. Van Steekelenburg J, Clement PH, Beel MH (2002) Comparison of five new antihistamines (H1 receptor antagonists) in patients with allergic rhinitis using nasal provocation studies and skin tests. Allergy 57(4): 346-350.

70. Dhand A, Aminoff MJ (2014) The neurology of itch. Brain 137(2): 31-22.

71. Nelson HS (2003) Prospects for antihistamines in the treatment of asthma. J Allergy Clin Immunol 112(4S): S96-S100.

72. Portnoy JM, Dinakar C (2004) Review of cetrizine hydrochloride for the treatment of allergic disorders. Expert Opin Pharmacother 5(1): $125-135$

73. Schwarzer GT, Bassler D, Mitra A, Ducharme FM, Forster J (2004) Ketotifen alone or as additional medication for long-term control of asthma and wheeze in children. Cochrane Database Syst Rev (1): 001384.

74. Cipandri G, Passalacqua G, Mincarini M, Ricca V, Canonica GW (1997) Continuous versus on demand treatment with cetrizine for allergic rhinitis. Ann Allergy Asthma Immunol 79(6): 507-511.

75. Leurs R,Church MK, Taglialatela M (2002) H1-antihistamines:inverse agonism, anti-inflammatory actions and cardiac effects. Clin Exp Allergy 32(4): 489-498.

76. Weller JM, Bloodfield JR, Woodworth GG, Grant AR, Layton TA, et al. (2000) Effects of fexofenadine,diphenhydramine and alcohol on 


\section{Global Journal of Otolaryngology}

driving performance: A randomized placebo-controlled trial in the Iowa driving simulator. Ann Intern Med 132(5): 354-363.

77. Gray SL, Anderson ML, Dublin S, Hanlon JT, Hubbard R, et al. (2015) Cumulative use of strong anticholinergics and incident dementia: a prospective cohort study. JAMA Intern Med 175(3): 401-407.

78. Olasinska Wisniewska A, Olasinski J, Grajek S (2014) Cardiovascular safety of antihistamines. Postepy Dermatol Allergol 31(3): 182-186.

79. Davila I, Sastre J, Bartra J, del Cuvillo A, Jáuregui I, et al. (2006) Effect of $\mathrm{H} 1$ antihsitamines upon the cardiovascular system. J Investig Allergol Clin Immunol 16(S1): 13-23.

80. Poluzzi E, Raschi E, Godman B, Ariola Koci, Ugo Moretti, et al. (2015) Pro-arrythmic potential of oral antihistamines (H1),combining adverse event reports with drug utilization data across Europe. Plos One 10: e1119551.

81. Juniper EF, Kline PA, Hargreave FE, Dolovich J (1989) Comparison of beclometasone dipropionate aqueous nasal spray, astimezole, and the combination in the prophylactic treatment of ragweed polleninduced rhinoconjuctivitis. Allergy Clin Immunol 83(3): 627-633.

82. Ratner PH, Van Bavel JH, Martin BG, Hampel FC, Howland WC, et al. (1998) A comparison of the efficacy of fluticasone propionate aqueous nasal spray and loratidine alone or in combination, for the treatment of seasonal allergic rhinitis. J Fam Pract 47(2): 118-125.

83. Simpson RJ (1994) Budosenide and terfenadine, separately and in combination in the treatment of hay fever. Ann Allergy 73(6): 497502 .

84. Lee TA, Pickard AS (2007) Meta-analysis of azelastine nasal spray for the treatment of allergic rhinitis. Pharmacotherapy 27(6): 852859.

85. Horak F (2008) Effectiveness of twice daily azelastine nasal spray in patients with seasonal allergic rhinitis. Ther Cln Risk Manag 4(5): 1009-1022.

86. Lieberman P, Kaliner M, Wheeler WJ (2005) Open-label evaluation of azelastine nasal spray in patients with seasonal allegic rhinitis and non-allergic vasomotor rhinitis. Curr Med Res Opin 21(4): 611618.

87. Horak F, Zieglmayer UP, Zieglmayer R, Kavina A, Marschall K, et al. (2006) Azelastine nasal spray and desloratidine tablets in pollleninduced seasonal allergic rhinitis: a pharmocodynamic study of onset of action and efficacy. Curr Med Res Opin 22(1): 151-157.

88. La Force CE, Corren J, Wheeler WJ, Berger WE (2004) Efficacy of azelastine nasal spray in seasonal allergic rhinitis patients who remain symptomatic after treatment with fexofenadine. Ann Allergy Asthma Immunol 93(2): 154-159.

89. Yanez A, Rodrigo GJ (2002) Intranasal corticosteroids versus topical $\mathrm{H} 1$ receptor antagonists for the treatment of allergic rhinitis: a systematic review with meta-analysis. Ann Allergy Asthma Immunol 89(5): 479-484.

90. Bielory B, Bielory L (2014) Over the counter migration of steroid use: impact on the eye. Curr Opin Allergy Clin Immunol 14(5): 471476.

91. Hong J, Bielory B, Rosenberg JL, Bielory L (2011) Efficacy of intranasal corticosteroids for the ocular symptoms of allergic rhinitis: a systematic review. Allergy Asthma Proc 32(1): 22-25.

92. Keith PK, Scadding GK (2009) Are intranasal corticosteroids all equally consistent in managing ocular symptoms of seasonal allergic rhinitis? Curr Med Res Opin 25(8): 2021-2041.

93. Weiner JM, Abramson MJ, Puy RM (1998) Intranasal corticosteroids versus $\mathrm{H} 1$ receptor antagonists in rhinitis:systematic review of randomized controlled trials. BMJ 317(7173):1624-1629.
94. Graft D, Aaronson D, Chervinsky P, Kaiser H, Melamed J, et al. (1996) A placebo- and active-controlled randomized trial of prophylactic treatment of seasonal allergic rhinitis with mometasone fuorate aqueous nasal spray. J Allergy Clin Immunol 98(4): 724-731.

95. Derendorfer H, Meltzer EO (2008) Molecular and clinical pharmacology of intranasal corticosteroids: clinical and therapeutic implications. Allergy 63(10): 1292-1300.

96. Homer J, Gazis TG (1999) Cushing's syndrome induced by betamethasone nose drops. In rhinological disease betametasone should be regarded as systemic corticosteroid. BMJ 312(7194):1355.

97. Bui CM, Chen H, Shyr Y, Joos KM (2005) Discontinuing nasal steroids might lower intraocular pressure in glaucoma. J Allergy Clin Immunol 116(5): 1042-1047.

98. Bousquet J, Van CP, Khaltaev N, Aria Workshop Group, World Health Organization (2011) Allergic rhinitis and its impact on asthma. J Allergy Clin Immunol 108(5S): S147-S334.

99. Pullerits T, Praks L, Ristoja V, Lötvall J (2002) Comparison of a nasal glucocorticoid, antileukotriene and a combination of antileukotriene and antihistamine in the treatment of seasonal allergic rhinitis. J Allergy Clin Immunol 109(6): 949-955.

100. Wilson A., Orr LC, Sims EJ, Lipworth BJ (2001) Effects of monotherapy with intra-nasal corticosteroid or combined oral histamine and leukotriene receptor antagonists in seasonal allergic rhinitis. Clin Exp Allergy 31(1): 61-68.

101. Meltzer EO, LaForce C, Rainer P, Price D, Ginsberg D, et al. (2012) MP 29-02 (a novel intranasal formulation of azelastine hydrochloride and fluticasone propionate) in the treatment of seasonal allergic rhinitis: a randomized double-blind placebo-controlled trial of efficacy and safety. Allergy Asthma Proc 33(4): 324-332.

102. Price D, Shah S, Bathia S, Bachert C, Berger W, et al. (2013) A new therapy (MP 29-02) is effective for the long-term treatment of chronic rhinitis. J Investig Allergol Clin Immunol 23(7): 495-503.

103. Barnes ML, Biallosterski BT, Gray RD, Fardon TC, Lipworth BJ (2005) Decongestant effects on nasal xylometazoline and momestatone fuorate in persistent allergic rhinitis. Rhinology 43(4): 291-295.

104. Baroody FM, Brown D, Gavanescu L, DeTineo M, Naclerio RM (2011) Oxymetazoline adds to the effectiviness of fluticasone fuorate in the treatment of perennial allergic rhinitis. J Allergy Clin Immunol 127(4): 927-934.

105. Skadding GK (1995) Rhinitis medicamentosa. Clin Exp Allergy 25(5): 391-394.

106. Baroody FM, Naclerio RM (2011) Nasal-ocular reflexes and their role in the management of allergic rhinoconjunctivitis with intranasal steroids. World Allergy J 4(1S): S1-S5.

107. Malm L (1994) Pharmacologic background to decongesting and anti-inflammatory treatment of rhinitis and sinusitis. Acta Otolaryngol 515: 53-55.

108. Naclerio RM (1998) Optimizing treatment options. Clin Exp Allergy 28(S6): 54-59.

109. Barnes NC (2000) Effects of Antileukotrienes in the Treatment of Asthma. Am J Resp Crit Care Med 161: S1.

110. Philip G, Malmstrom K, Hampel FC, Weinstein SF, LaForce CF, et al. (2002) Montelukast for treating seasonal rhinitis: a randomized,double-blind,placebo-controlled trial performed in the spring. Clin Exp Allergy 32(7): 1020-1028.

111. Pulleritis T, Praks L, Skoogh BE, Ani R, Lötvall J (1999) Randomized placebo-controlled study comparing a leukotriene receptor antagonist and a nasal glucocorticoid in seasonal allergic rhinitis. Am J Resp Crit Care Med 159(6): 1814-1816. 
112. Ratner PH, Howland WC, Arastu R, et al. Philpot EE, Klein KC, et al. (2003) Fluticasone propionate aqueous nasal spray provided significantly greater improvement in daytime and nighttime nasal symptoms of seasonal allergic rhinitis compared with montelukast. Ann Allergy Asthma Immunol 90(5): 536-542.

113. Wilson AM, Dempsey OJ, Sims EJ, Lipworth BJ (2001) A comparison of topical budosenide and oral montelukast in seasonal allergic rhinitis. Clin Exp Allergy 31(4): 616-624.

114. Fowler SJ, Hall IP, Wilson AM, Wheatley AP, Lipworth BJ (2002) 5-Lopoxygenase polymorphism and in vivo response to leukotriene receptor antagonists. Eur J Clin Pharmacol 58(3): 187-190.

115. Mastalerz L, Nizankowska E, Sanak M, Mejza F, Pierzchalska M, et al. (2002) Clinical and genetic features underlying the response of patients with bronchial asthma to treatment with a leukotriene receptor antagonist. Eur J Clin Invest 32(12): 949-955.

116. Sampson AP, Siddiqui S, Buchanan D, Howarth PH, Holgate ST, et al. (2000) Variant LCT(4) synthetase allele modifies cysternyl leukotriene synthesis in eosinophils and predicts clinical response to zafirlukast. Thorax 55(S2): 528-531.

117. Meltzer EO, Malmstrom K, Lu S, Prenner BM, Wei LX, et al. (2000) Concomittant montelukast and loratidine as treatment for seasonal allergic rhinitis: a randomized placebo-controlled clinical trial. J Allergy Clin Immunol 105(5): 917-922.

118. Nayak AS, Philip G, Lu S, Malice MP, Reiss TF, et al. (2002) Efficacy and tolerability of montelukast alone or in combination with loratidine in seasonal allergy rhinitis: a multicenter, randomized, double blind, placebo-controlled trial performed in the fall. Ann Allergy Asthma Immunol 88(6): 592-600.

119. Wilson AM, Orr LC, Coutie WJ, Sims EJ, Lipworth BJ (2002) A comparison of once daily fexofenadine versus the combination of montelukast plus loratidine on domicillary nasal peak flow and symptoms in seasonal allergic rhinitis. Clin Exp Allergy 32(1): 126132.

120. Wilson AM, White PS, Gardiner Q, Nassif R, Lipworth BJ (2001) Effects of leukotriene receptor antagonist therapy in patients with chronic rhinosinusitis in a real life rhinology clinical setting. Rhinology 39(3): 142-146.

121. Philip G, Nayak AS, Berger WE, Leynadier F, Vrijens F, et al. (2004) The effect of montelukast on rhinitis symptoms in patients with asthma and allergic rhinitis. Curr Med Res Opin 20(10): 1549-1558.

122. Hauser T, Mahr A, Metzler C, Coste J, Sommerstein R, et al. (2008) The leucotriene receptor antagonist montelukast and the risk of Churg-Strauss syndrome; a case-crossover study. Thorax 63(8): 677-682.

123. Nathan N, Little MA, Kunst H, D Wilson, Thickett (2008) ChurgStrauss syndrome and leukotriene antagonist use: a respiratory perspective. Thorax 63(10): 883-888.

124. Tan R, Corren J (1995) Optimum treatment of rhinitis in the elderly. Drugs Aging 7(3): 168-175.

125. Grossmann J, Banov C, Boggs BP, Bronsky EA, Dockhorn RJ et al. (1995) Use of ipratropium bromide nasal spray in chronic treatment of nonallergic perennial rhinitis,alone and in combination with other perennial rhinitis medications. J Allergy Clin Immunol 95(2): 1123-1127.

126. Kayser HB, Findlay SR, Georgitis JW, Grossman J, Ratner PH, et al (1988) The anticholinergic agent,ipratropium bromide is useful in the treatment of rhinorrhea associated with perennial allergic rhinitis. Allergy Asthma Proc 19(1): 23-29.

127. Meltzer EO, Orgel HA, Bronsky EA, Findlay SR, Georgitis JW, et al. (1992) Ipratropium bromide aqueous nasal spray for patients with perennial allergic rhinitis:a study of its effects on their symptoms,quality of life and nasal cytology. J Allergy Clin Immunol 90(2): 242-249.

128. Dockhorn R, Aaronson D, Bronsky E, Chervinsky P, Cohen R, et al (1999) Ann Allergy Asthma Immunol 82(4): 349-359.

129. Ratner PH, Ehrlich PM, Fineman SM, Meltzer EO, Skoner DP (2002) Use of intranasal cromolyn sodium for allergic rhinitis. Mayo Clin Proc 77(4): 350-354.

130. James JG, Campbell LM, Harrison JM, Fell PJ, Ellers-Lenz B, et al. (2003) Comparison of the efficacy and tolerability of topically administered azelastine,sodium cromoglycate and placebo in the treatment of seasonal allergic conjunctiviis and rhinoconjunctivitis. Curr Med Res Opin 19(4): 313-320.

131. Meltzer EO (2002) Efficacy and patient satisfaction with cromolyn sodium nasal solution in the treatment of seasonal allergic rhinitis: a placebo-controlled study. Clin Ther 24(6): 942-952.

132. Owen CG, Shah A, Henshaw K, Smeeth L, Sheikh A (2004) Topical treatments for seasonal allergic conjunctivitis: systematic review and meta-analysis of efficacy and effectivenes. Br J Gen Pract 54(503): 451-456.

133. Calderon MA, Demoly P, Gerth van Wijk P, Bousquet J, Sheikh A et al. (2012) EAACI: A European Declaration on Immunotherapy Designing the future of allergen specific immunotherapy. Clin Transl Allergy 2(1): 20 .

134. Calderon M, Cardona V, Demoly P (2012) One hundred years of allergen immune therapy European Academy of Allergy and Clinical Immunology celebration:review of unanswered questions. Allergy 67(4): 462-476.

135. Calderon MA, Alves B, Jacobson M, Hurwitz B, Sheikh A, et al. (2007) Allergen injection immunotherapy for seasonal allergic rhinitis. Cochrane Database Syst Rev 1: CD001936.

136. Erokosima N, Suarez-Cuervo C, Ramanathan M, Kim JM, Chelladurai $Y$, et al. (2014) Effectiveness of subcutaneous immunotherapy for allergic rhinoconjunctivitis and asthma: a systematic review. Laryngoscope 124(3): 616-627.

137. Eifan AO, Calderon MA, Durham SR (2013) Allergen immunotherapy for house dust mite:clinical efficacy and immunogical mechanisms in allergic rhinitis and asthma. Expert Opin Biol Ther 13(11): 15431556.

138. Alvarez-Cuesta E, Cuesta-Herranz J, Payana-Ruiz J, Cuesta-Herranz C, Blanco-Quirós A (1994) Monoclonal antibody-standardized cat extract immunotherapy: risk-benefits from a double-blind placebo study. J Allergy Clin Immunol 93(3): 556-566.

139. Varney VA, Edwards J, Tabbah K, Brewster H, Mavroleon G, et al (1997) Clinical efficacy of specific immunotherapy to cat dander; a double-blind-placebo-controlled trial. Clin Exp Allergy 27(8): 860867.

140. Alvarez-Cuesta O, Bousquet J, Canonica GW, Durham SR, Malling HJ, et al. (2006) Standards for practical allergen-specific immunotherapy. Allergy 61(S82): 1-20.

141. Radulovic S, Wilson D, Calderon M, Durham S (2011) Systematic reviews of sublingual immunotherapy (SLIT). Allergy 66(6): 740752.

142. Lin SY, Erekosima N, Kim JM, Ramanathan M, Suarez-Cuervo C, et al. (2013) Sublingual immunotherapy for the treatment of allergic rhinoconjunctivitis and asthma; a systematic review. JAMA 309(12): 1278-1288.

143. Kim JM, Lin SY, Suarez-Cuervo C, Yohalakshmi Chelladurai, Murugappan Ramanathan, et al. (2013) Allergen-specific immunotherapy for pediatric asthma and rhinoconjunctivitis: a systematic review. inPediatrics 131(6): 1155-1167. 
144. Calderon MA, Boyle RJ, Penagos M, Sheikh A (2011) Immunotherapy: the meta-analyses. What have we learned? Immunol Allergy. Clin North Am 31(2): 159-173.

145. Nieto A, Mazon A, Pamies R, Bruno L, Navarro M, et al. (2009) Sublingual immunotherapy for allergic respiratory diseases: an evaluation of meta-analyses. Clin Im J Allergy Clin Immunol 124(1): 157-161.

146. Zenner HP, Baumgarten C, Rasp G, Fuchs T, Kunkel G, et al. (1997) Short-term immunotherapy: a prospective randomized,doubleblind,placebo-controlled multicenter study of molecular standardized grass and rye allergens in patients with grass polleninduced allergic rhinitis. J Allergy Clin Immunol 100(1): 23-29.

147. Frew AJ, Powell RJ, Corrigan CJ, Durham SR, UK Immunotherapy Study Group (2006) Efficacy and safety of specific immunotherapy with SQ allergen extract in treatment-resistant seasonal allergic rhinoconjunctivitis. J Allergy Clin Immunol 117(2): 319-325.

148. Normansell R, Kew KM, Bridgman A (2015) Sublingual immunotherapy for asthma. Cochrane Database Syst Rev 8: CD011293.

149. (2017) FDA US Food \& Drug Administration. FDA News Release. FDA approves Odactra for house dust mite allergies. For Immediate Release.

150. Durham SR, Walker SM, Varga EM, Jacobson MR, O’Brien F, et al. (1999) Long-term clinical efficacy of grass-pollen immunotherapy. N Engl J Med 341(7): 468-475.
151. Didler A, Malling HJ, Worm M, Horak F, Sussman G, et al. (2013) Post-treatment efficacy of discontinous treatment with 300IR5grass pollen sublingual tablet in adults with grass pollen-induced allergen rhinoconjunctivitis. Clin Exp Allergy 43(5): 568-577.

152. Durham SR, Emminger W, Kapp A, De Monchy JG, Rak S, et al. (2012) SQ-standardized sublingual grass immunotherapy:confirmation of disease modification 2 years after 3 years of treatment in a randomized trial. J Allergy Clin Immunol 129(3): 717-725.

153. Jacobson L, Niggeman B, Dreborg S, Ferdousi HA, Halken S, et al. (2007) Specific immunotherapy has long term preventive effect of seasonal and perennial asthma: 10 year follow-up on the PAT study. Allergy 62(8): 943-948.

154. Des RA, Paradis L, Menardo JL, Bouges S, Daurés JP, et al. (1997) Immunotherapy with a standardized Dermatophagoides pteronyssinus extract VI. Specific immunotherapy prevents the onset of new sensitazations in children. J Allergy Clin Immunol 99(4): 450-453.

155. Pajno GB, Barberio G, De LF, S Parmiani, L Morabito (2001) Prevention of new sensitizations in asthmatic children monosensitized to house dust mite by specific immunotherapy, A six year follow-up study. Clin Exp Allergy 31(2)S: 1392-1397.

\section{Your next submission with Juniper Publishers will reach you the below assets}

- Quality Editorial service

- Swift Peer Review

- Reprints availability

- E-prints Service

- Manuscript Podcast for convenient understanding

- Global attainment for your research

- Manuscript accessibility in different formats

( Pdf, E-pub, Full Text, Audio)

- Unceasing customer service

Track the below URL for one-step submission https://juniperpublishers.com/online-submission.php 